\title{
PENGARUH PENERAPAN ACTIVE, JOYFUL, AND EFFECTIVE LEARNING (AJEL) PADA MATERI PERUBAHAN LINGKUNGAN TERHADAP SIKAP PEDULI LINGKUNGAN SISWA
}

\author{
The Effect of the Application of Active, Joyful And Effective Learning \\ (AJEL) On Environmental Changes Material to Environmentally Care Attitude of \\ Student
}

Supriyatin, Erna Heryanti, Nurnawati

Pendidikan Biologi Fakultas MIPA Universitas Negeri Jakarta

Email: erna.heryanti@gmail.com

\begin{abstract}
The aim of the research was to analyze the effect of the application of Active, Joyful and Effective Learning (AJEL) to environmentally care attitude of students in X grade of 33 Senior High School of Jakarta. Sample was collected by a cluster random sampling technique with one experimental class, namely class X-Science 1, whereas X-Science 3 as control class with a total sample of 62. This study was a Quasi Experimental Method with Non-Randomized Control Group PretestPosttest Design. Components of learning model that reflects the Active, Joyful and Effective Learning (AJEL) that used in this research was time token, gallery walk, and outdoor learning. After doing normality test (Kolmogorov Smirnov Test) and homogeneous test (Fisher Test), known that data had normal distribution and homogeneous. Increase in environmentally care attitude measured use N-Gain test. Result of the test are, in experimental class, $\mathrm{N}$-Gain score is 52,8 which includes into middle increased categories. In control class, N-Gain score is 24,8 which includes into low increased categories. Result of calculation hypothesis test (t-test) indicated there was an effect of the application of Active, Joyful and Effective Learning (AJEL) to environmentally care attitude of students.
\end{abstract}

Keywords : Active, joyful and effective learning (AJEL), environmentally care attitude.

\section{PENDAHULUAN}

Lingkungan merupakan bagian yang penting bagi kehidupan manusia. Kerusakan lingkungan hidup akibat aktivitas manusia salah satunya disebabkan oleh kurangnya pengetahuan tentang lingkungan dan rendahnya sikap peduli lingkungan (Schatz, 2000).

Sikap peduli lingkungan dapat ditanamkan di lingkungan sekolah. Hal ini berdasarkan surat keputusan bersama Menteri Lingkungan Hidup dan Menteri Pendidikan Nasional No. Kep. 07/MenLH/06/2005 dan No. 05/VI/KB/2005 tentang

pembinaan dan pengembangan pendidikan lingkungan hidup, bahwa pendidikan lingkungan hidup dilakukan secara terintegrasi dengan mata pelajaran yang ada. 
Salah satu materi dari mata pelajaran biologi yang membahas hubungan manusia dengan lingkungan adalah materi perubahan lingkungan. Selama ini model pembelajaran di sekolah kurang menarik dan kurang tepat dalam membawakan materi tersebut.

Berdasarkan hasil wawancara dengan siswa kelas X SMA Negeri 33 Jakarta, materi perubahan lingkungan dianggap sebagai materi yang mudah tetapi membosankan. Sehingga perlu diterapkan pendekatan Active, Joyful and Effective Learning (AJEL) yang menuntut siswa aktif selama pembelajaran (active learning), siswa mengalami langsung dan pembelajaran berpusat pada siswa (student-centered learning) sehingga siswa dapat membangun pengetahuannya sendiri (Suharyanto, 2009).

AJEL merupakan salah satu pendekatan yang digunakan guru untuk menciptakan pembelajaran yang aktif, efektif dan menyenangkan. Pembelajaran AJEL terdiri dari beberapa metode, antara lain Active Learning (pembelajaran aktif), Joyful Learning (pembelajaran menyenangkan), dan Effective Learning (pembelajaran efektif).

Dengan penerapan AJEL, siswa menjadi bersemangat belajar, siswa benarbenar memahami konsep, mengalami sendiri dan terlibat dalam pembelajaran, hal itu menjadikan pengetahuan siswa terhadap lingkungan semakin meningkat. Dengan pengetahuan yang maksimal mengenai lingkungan, maka akan terbentuk sikap dalam hal ini berupa sikap peduli lingkungan, dikarenakan AJEL diterapkan pada materi perubahan lingkungan (Ma'aruf, 2009).

Menurut Azwar (2003) bahwa sikap dapat dibentuk dan salah satu aspek pembentuk sikap adalah komponen kognisi. Komponen kognisi berisi kepercayaan seseorang mengenai kebenaran suatu konsep. Kepercayaan dapat terus berkembang jika dipengaruhi oleh pengalaman pribadi dan orang lain. Dengan pengetahuan mengenai lingkungan yang baik serta pengalaman belajar yang baik maka dapat terbentuk sikap yang dalam hal ini adalah sikap peduli lingkungan siswa karena AJEL diterapkan pada materi perubahan lingkungan.

\section{METODE}

Metode yang digunakan adalah kuasi eksperimen. Variabel bebas adalah penerapan Active, Joyful, and Effective Learning (AJEL). Variabel terikat adalah sikap peduli lingkungan siswa. Penelitian ini dilaksanakan di SMA Negeri 33 Jakarta, pada bulan Mei 2016. Sampel yang digunakan pada penelitian ini sebanyak 62 siswa SMA Negeri 33 Jakarta yang ditentukan dengan cara simple random sampling.

\section{PROSEDUR ANALISIS DATA}

Data yang diperoleh dikonversikan ke dalam bentuk nilai, kemudian dicari peningkatannya menggunakan uji $N$-Gain. yaitu normalisasi gain yang diperoleh dari hasil pretest dan posttest, perhitungan nilai rata-rata $N$-Gain dilakukan untuk melihat peningkatan sikap peduli lingkungan siswa. Selanjutnya skor $N$-Gain juga akan digunakan untuk melakukan analisis data yang mencakup uji normalitas, uji homogenitas, dan uji hipotesis penelitian. 


\section{HASIL DAN PEMBAHASAN \\ Hasil}

Penelitian dilakukan pada dua kelas. Satu kelas eksperimen yang menerapkan AJEL dan satu kelas kontrol yang menerapkan STAD. Penerapan AJEL menggunakan tiga model pembelajaran yakni time token, outdoor study, dan gallery walk.

Hari pertama pemberian pretest di kelas eksperimen dan kontrol. Lalu kelas eksperimen melakukan pembelajaran dengan model time token, seperti yang terlihat di kelas bahwa siswa aktif menggali pengetahuan dan mengemukakan pendapat serta menanggapi pendapat temannya. Siswa mendapatkan banyak ilmu mengenai lingkungan bukan hanya dari diri sendiri melainkan dari teman dan guru. Pengetahuan kognitif mengenai konsep lingkungan tersebut yang akan menjadi dasar terbentuknya sikap. Sedangkan kelas kontrol pertemuan pertama, siswa dan guru melakukan kegiatan tanya jawab dan diskusi kelompok terkait dasar-dasar konsep perubahan lingkungan.

Pertemuan kedua model gallery walk. Siswa ditugaskan membuat produk daur ulang limbah, kemudian dipresentasikan dengan gallery walk sehingga pembelajaran menyenangkan. Seperti terlihat di dalam kelas, siswa antusias dalam belajar karena pembelajaran berlangsung menyenangkan, pengetahuan siswa tentang penanganan limbah anorganik bertambah. Siswa berniat untuk menghargai lingkungan, mengurangi jumlah sampah dan memanfaatkan barang bekas untuk didaur ulang. Pertemuan kedua kelas kontrol, guru menjelaskan dampak pencemaran dan upaya mengatasinya. Kemudian siswa mempresentasikan mengenai macam pencemaran dan cara menanggulanginya.

Pertemuan terakhir model outdoor study, siswa terjun langsung ke lapangan mengamati, menganalisis tipe kerusakan, penyebab dan penanggulangannya berbantuan lembar kerja siswa dengan tagihan berupa laporan hasil pengamatan yang dipresentasikan dan didiskusikan. Dalam model ini, siswa bukan hanya belajar dari teori buku sekolah, namun siswa mengalami langsung di lingkungan sekitarnya. Belajar di lapangan dan mengalami langsung akan membuat siswa memahami apa yang dipelajari. Pertemuan terakhir kelas kontrol dilaksanakan dengan presentasi di depan kelas mengenai tugas membuat produk daur ulang limbah anorganik yang dikerjakan berkelompok. Pertemuan terakhir, yakni pemberian posttest di kelas eksperimen dan kelas kontrol.

Hasil penelitian meliputi data sikap peduli lingkungan siswa, keterlaksanaan pembelajaran, dan wawancara tanggapan siswa dan guru. Hasil rata-rata pretest kelas eksperimen dan kontrol didapatkan rata-rata nilai yang hampir sama, yaitu kelas eksperimen sebesar 70,5 dan kelas kontrol sebesar 72,2 yang berarti antara kelas eksperimen dan kontrol memiliki sikap awal yang sama. Hasil rata-rata posttest kelas eksperimen dan kontrol didapatkan rata-rata nilai yang berbeda, yaitu kelas eksperimen sebesar 86,1 dan kelas kontrol sebesar 79,0 yang berarti terjadi perubahan sikap pada kelas eksperimen yang menerapkan AJEL pada pembelajaran.

Uji N-Gain untuk menguji peningkatan sikap peduli lingkungan siswa setelah dilakukan pembelajaran dengan AJEL. Peningkatan kelas eksperimen lebih tinggi dibandingkan dengan kelas kontrol. Rata-rata skor N-Gain kelas eksperimen sebesar 52,8 termasuk kategori peningkatan sedang. Rata-rata skor NGain kelas kontrol sebesar 24,8 termasuk kategori peningkatan rendah. 


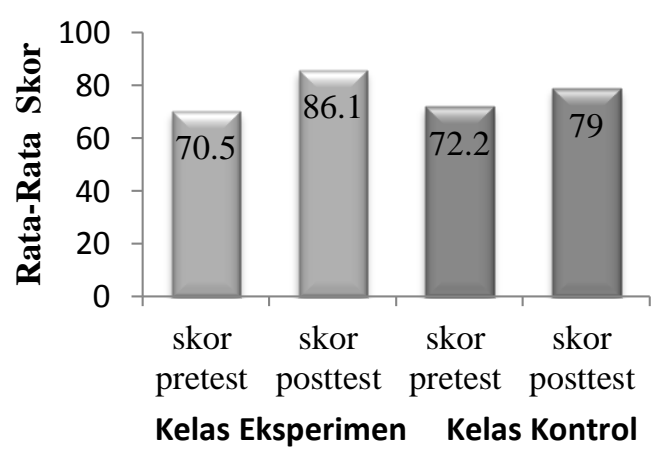

Gambar 1. Perbandingan rata-rata skor pretest-posttest kelas eksperimen dan kontrol

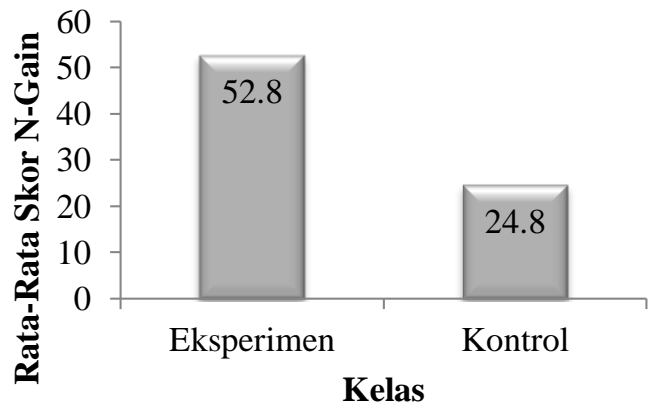

Gambar 2. Perbandingan rata-rata skor $N$-Gain kelas eksperimen dan control Tabel 1. Hasil analisis uji t rata-rata skor $N$-Gain kelas eksperimen dan control

\begin{tabular}{|c|c|c|c|c|c|}
\hline Kelas & $\begin{array}{c}\text { Nilai } \\
\text { N-Gain }\end{array}$ & $\mathbf{N}$ & $\stackrel{\text { T }}{\text { hitung }}$ & $\begin{array}{c}\mathrm{t} \\
\text { tabel } \\
(\alpha 5 \%)\end{array}$ & Ket \\
\hline Eksperimen & 52,8 & 31 & 6,3 & 1,67 & $\begin{array}{l}\text { Ada perbe- } \\
\text { daan signi- } \\
\text { fikan }\end{array}$ \\
\hline
\end{tabular}

\section{Pembahasan}

Berdasarkan hasil analisis data yang dilakukan, menunjukkan pembelajaran dengan AJEL berpengaruh terhadap sikap peduli lingkungan siswa. AJEL merupakan pendekatan pembelajaran yang menuntut siswa aktif selama pembelajaran (active learning), siswa mengalami langsung dan pembelajaran berpusat pada siswa (student-centered learning) sehingga siswa dapat membangun pengetahuannya sendiri (Suharyanto, 2009).

Pelaksanaan beberapa model pembelajaran sebagai komponen AJEL dalam kelas eksperimen memberikan suasana yang berbeda pada kegiatan pembelajaran. Hal ini membuat siswa merasa mudah dan nyaman dalam mengikuti pembelajaran. Kegiatan inilah yang membedakan dengan kegiatan pembelajaran pada kelas kontrol. Hal ini serupa dengan penelitian Kusumajati (2010), AJEL membuat siswa menjadi aktif selama pembelajaran, merasa lebih bersemangat, lebih senang, lebih tertantang dan pembelajaran menjadi lebih efektif.

Pembelajaran model time token dalam kelas menuntut siswa untuk berpartisipasi aktif dalam mengungkapkan pendapat atau pertanyaan mengenai 
lingkungan, sehingga siswa lebih berpikir kritis mengenai apa yang akan disampaikan dan ditanyakan di depan kelas. Model time token dapat merangsang siswa aktif dalam kegiatan pembelajaran (Wiyarsih, 2010).

Meskipun awalnya siswa terkesan malu-malu karena tidak terbiasa, namun dengan dibagikannya kupon bicara, siswa menjadi lebih bersemangat. Siswa yang belum terbiasa mengungkapkan pendapat di depan teman-teman satu kelas, akan mulai terlatih sedikit demi sedikit untuk aktif berbicara di depan umum. Siswa yang memang aktif selama pembelajaran pun dengan model time token ini ditekan keaktifannya sehingga tidak mendominasi pembelajaran di kelas dan berusaha menghargai temannya.

Kegiatan gallery walk pada pertemuan berikutnya merupakan aplikasi dari joyful learning. Siswa tidak hanya berdiam diri duduk di kursi, tetapi mereka berkeliling stand antar kelompok untuk belajar bersama tentang limbah. Siswa terlihat lebih menikmati suasana pembelajaran karena tidak hanya mendengarkan apa yang disampaikan guru, tetapi mereka juga memberikan materi kepada temannya, layaknya tutor sebaya. Siswa menjadi lebih memahami pentingnya daur ulang limbah. Hal ini sejalan dengan penelitian Choirunnisa (2014), penerapan AJEL membuat suasana pembelajaran menjadi menyenangkan karena siswa tidak merasa tertekan selama pembelajaran.

Pertemuan terakhir, pembelajaran dengan outdoor study, disamping siswa merasakan suasana baru ketika proses pembelajaran berlangsung, mereka juga mengaku lebih mengenal lingkungan sekitar dengan adanya kegiatan observasi lapangan ini. Sejalan dengan penelitian Indah (2014), pembelajaran dengan outdoor study berpengaruh terhadap kepedulian siswa pada lingkungan karena siswa mendapat pengalaman langsung untuk mengamati dan mengumpulkan data perubahan, pencemaran, dan kerusakan lingkungan.

Ketiga kegiatan pembelajaran tersebut dapat menumbuhkan sikap peduli lingkungan siswa. Disamping siswa telah mendapat pengetahuan melalui pertemuan pertama dan diperkuat oleh pertemuan kedua kemudian siswa mendapat pengalaman langsung dari pertemuan ketiga. Sesuai dengan pernyataan Azwar (2003) bahwa sikap dapat dibentuk dan salah satu aspek pembentuk sikap adalah komponen kognisi. Komponen kognisi berisi kepercayaan seseorang mengenai kebenaran suatu konsep. Kepercayaan dapat terus berkembang jika dipengaruhi oleh pengalaman pribadi dan orang lain.

AJEL mampu membangun minat siswa serta dapat mempermudah pemahaman siswa karena pembelajaran dilakukan dengan melibatkan siswa secara langsung. Siswa terjun langsung pada kegiatan observasi di lingkungan sekitar sehingga membuat siswa tertarik dan bersemangat dalam mengikuti pembelajaran. Siswa memanfaatkan limbah untuk diolah menjadi produk daur ulang, mampu memberikan suasana yang berbeda dari pembelajaran biasa yang membuat siswa tidak bosan dan terasa menyenangkan. Siswa menjadi lebih mengenal lingkungan sekitar dan siswa menjadi lebih peduli terhadap lingkungan.

Sikap peduli lingkungan siswa dianalisis melalui laporan observasi siswa setelah melakukan observasi lapangan. Lima dari enam kelompok memiliki laporan yang sesuai dengan kondisi di lapangan. Siswa mengungkapkan hasil observasi berupa adanya pencemaran yang bersumber dari sampah dan adanya pencemaran di selokan, serta pencemaran udara berupa asap pembakaran sampah di lingkungan sekitar sekolah dan asap dari kendaraan bermotor yang 
menimbulkan polusi udara. Hasil tersebut merupakan keadaan nyata yang ditemui di lapangan.

Solusi yang diberikan oleh siswa melalui laporan tersebut sudah sesuai dengan permasalahan yang ditemui, hal ini menunjukkan adanya peningkatan sikap peduli lingkungan siswa. Pada laporan observasi tersebut siswa tidak hanya mengungkapkan fakta, tetapi ada beberapa kelompok yang turut mengungkapkan pendapatnya juga.

Sikap peduli lingkungan siswa kelas eksperimen mulai teramati oleh guru, meskipun baru berupa tindakan kecil, seperti ruangan kelas yang menjadi lebih bersih, hal ini terlihat dari tidak adanya sampah berupa kertas, sisa buangan rautan pensil serta plastik jajanan makanan siswa di lantai kelas seperti biasanya. Hal lain yang teramati oleh guru yaitu ketika guru hendak memasuki ruang kelas setelah jam istirahat, ada beberapa siswa yang ijin keluar kelas untuk membuang sampah jajanan makanan di tong sampah yang terletak di luar kelas, biasanya siswa meletakkan sampah tersebut di laci meja tempat duduknya.

Sikap peduli lingkungan siswa juga teramati selama kegiatan outdoor study, yaitu siswa tetap menjaga kelestarian lingkungan selama pengamatan. Tidak terlihat adanya tindakan siswa yang merusak lingkungan seperti mencabuti tanaman di sekitar lingkungan sekolah ataupun ikut membuang sampah secara sembarangan.

Wawancara tanggapan siswa menyatakan mereka menjadi lebih memahami materi perubahan lingkungan dengan model pembelajaran time token, mengenal lingkungan sekitar melalui kegiatan outdoor study dan dengan kegiatan daur ulang limbah merupakan faktor utama timbulnya rasa semakin peduli terhadap lingkungan sekitar.

Siswa kelas eksperimen memberikan pernyataan positif dalam setiap aspek kegiatan pembelajaran AJEL pada materi perubahan lingkungan yang telah dilakukan. Hal ini menunjukkan bahwa dalam setiap kegiatan pembelajaran dengan penerapan AJEL, disukai oleh siswa kelas eksperimen. AJEL dapat membuat siswa untuk bersemangat dan termotivasi dalam mengikuti kegiatan belajar mengajar. Siswa merasa senang ketika proses pembelajaran, aktivitas siswa tinggi dan hasil belajar menjadi optimal. Dengan demikian, sikap peduli lingkungan siswa terbentuk pada siswa kelas eksperimen yang menerapkan AJEL pada pembelajaran.

Tercapainya peningkatan sikap peduli lingkungan siswa pada kelas eksperimen dan kelas kontrol tentunya tidak terlepas dari keterlaksanaan pembelajaran di dalam kelas. Rata-rata persentase keterlaksanaan pembelajaran pada kelas eksperimen dan kontrol masing-masing sebesar 100\%. Angka tersebut menunjukkan bahwa keterlaksanaan pembelajaran pada kelas eksperimen dan kelas kontrol terlaksana dengan sangat baik (Riduwan, 2010).

\section{KESIMPULAN}

Berdasarkan hasil penelitian dan pengujian hipotesis dapat disimpulkan bahwa penerapan Active, Joyful, and Effective Learning (AJEL) pada materi perubahan lingkungan berpengaruh terhadap sikap peduli lingkungan siswa. 


\section{DAFTAR PUSTAKA}

Azwar, S. 2003. Sikap Manusia, Teori dan Pengukurannya. Yogyakarta: Pustaka Pelajar

Choirunnisa, Iffa Faiza dan Andin Irsadi. 2014. Penerapan Active, Joyful, and Effective Learning (AJEL) berbasis Bioedutainment terhadap Hasil Belajar dan Keaktifan Siswa. Journal of Biology Education 3(3), 5.

Indah, Sondang Rosita. 2014. Pengaruh Metode Outdoor Learning melalui Pemanfaatan Hutan Kota terhadap Hasil Belajar dan Kepedulian Siswa pada Lingkungan. Tesis tidak diterbitkan. Jakarta: UNJ

Kusumajati, F. 2010. Upaya Mencapai Active, Joyful, Effective Learning (AJEL) dengan Menerapkan Pendekatan Structural Think Pair Share. Tesis tidak diterbitkan. Yogyakarta: UIN Sunan Kalijaga

Ma'aruf, Z. 2009. Implementasi Pembelajaran Aktif Kreatif Efektif dan Menyenangkan (PAKEM) untuk Pendidikan Sains di Sekolah. Jurnal Geliga Sains 3 (2): 19-28.

Republik Indonesia. 1997. Undang-Undang No.23 Tahun 1997 tentang Pengelolaan Lingkungan Hidup. Lembaran Negara RI Tahun 1997, No. 23. Jakarta: Sekretariat Negara

Riduwan. 2010. Metode \& Teknik Menyusun Proposal Penelitian. Bandung: Alfabeta

Schatz, C. 2000. Bringing Environmental Education and Outdoor Recreation Together. New York: SUNNY College at Cortland

Suharyanto, A. 2009. Peningkatan Kualitas Pendidikan Melalui Model Pembelajaran Kooperatif Berbasis Konstruktivisme. Jurnal Lembaran Ilmu Kependidikan 38(1): 68-77.

Wiyarsih, A. 2010. Implementation of Cooperative Learning Tipe Time Token to Increase The Student Activity and Interest Learning. Jurnal Pendidikan Kimia: UNY. 